\title{
RNA interference-mediated c-MYC inhibition prevents cell growth and decreases sensitivity to radio- and chemotherapy in childhood medulloblastoma cells
}

\author{
André O von Bueren ${ }^{1}$, Tarek Shalaby¹, Christoph Oehler-Jänne², \\ Lucia Arnold ${ }^{1}$, Duncan Stearns ${ }^{3}$, Charles G Eberhart ${ }^{3}$, Alexandre Arcaro ${ }^{4}$, \\ Martin Pruschy ${ }^{2}$ and Michael A Grotzer*1
}

Address: ${ }^{1}$ Neuro-Oncology Program, University Children's Hospital, Zurich, Switzerland, ${ }^{2}$ Department of Radiation Oncology, University Hospital Zurich, Zurich, Switzerland, ${ }^{3}$ Department of Pathology, Johns Hopkins University, Baltimore, Maryland, USA and ${ }^{4}$ Division of Clinical Chemistry and Biochemistry, University Children's Hospital, Zurich, Switzerland

Email: André O von Bueren - Andre.vonBueren@kispi.uzh.ch; Tarek Shalaby - Tarek.Shalaby@kispi.uzh.ch; Christoph OehlerJänne - oehlerc@mskcc.org; Lucia Arnold - alucia@gmx.ch; Duncan Stearns - steardu@jhmi.edu; Charles G Eberhart - ceberha@jhmi.edu; Alexandre Arcaro - Alexandre.Arcaro@kispi.uzh.ch; Martin Pruschy - Martin.Pruschy@usz.ch; Michael A Grotzer* - Michael.Grotzer@kispi.uzh.ch

* Corresponding author

Published: 10 January 2009

BMC Cancer 2009, 9:10 doi:10.1186/147I-2407-9-10

This article is available from: http://www.biomedcentral.com/I47I-2407/9/10

(C) 2009 von Bueren et al; licensee BioMed Central Ltd.

This is an Open Access article distributed under the terms of the Creative Commons Attribution License (http://creativecommons.org/licenses/by/2.0), which permits unrestricted use, distribution, and reproduction in any medium, provided the original work is properly cited.
Received: 2 April 2008

Accepted: 10 January 2009

\begin{abstract}
Background: With current treatment strategies, nearly half of all medulloblastoma (MB) patients die from progressive tumors. Accordingly, the identification of novel therapeutic strategies remains a major goal. Deregulation of $\mathrm{c}-\mathrm{MYC}$ is evident in numerous human cancers. In MB, overexpression of c-MYC has been shown to cause anaplasia and correlate with unfavorable prognosis.

Methods: To study the role of c-MYC in MB biology, we down-regulated c-MYC expression by using small interfering RNA (siRNA) and investigated changes in cellular proliferation, cell cycle analysis, apoptosis, telomere maintenance, and response to ionizing radiation (IR) and chemotherapeutics in a representative panel of human $M B$ cell lines expressing different levels of c-MYC (DAOY wild-type, DAOY transfected with the empty vector, DAOY transfected with cMYC, D34I, and D425).

Results: siRNA-mediated c-MYC down-regulation resulted in an inhibition of cellular proliferation and clonogenic growth, inhibition of GI-S phase cell cycle progression, and a decrease in human telomerase reverse transcriptase (hTERT) expression and telomerase activity. On the other hand, down-regulation of c-MYC reduced apoptosis and decreased the sensitivity of human MB cells to $I R$, cisplatin, and etoposide. This effect was more pronounced in DAOY cells expressing high levels of c-MYC when compared with DAOY wild-type or DAOY cells transfected with the empty vector.

Conclusion: In human MB cells, in addition to its roles in growth and proliferation, c-MYC is also a potent inducer of apoptosis. Therefore, targeting c-MYC might be of therapeutic benefit when used sequentially with chemo- and radiotherapy rather than concomitantly.
\end{abstract}




\section{Background}

Medulloblastomas (MB) are the most common malignant pediatric neoplasms of the central nervous system. $\mathrm{MB}$ constitute $20 \%$ of all pediatric brain tumors [1] and are characterized by their aggressive clinical behavior and a high risk of leptomeningeal dissemination. With current treatment strategies, nearly half of all patients eventually die from progressive tumors. Accordingly, the identification of novel therapeutic strategies remains a major goal.

The c-MYC proto-oncogene encodes a nuclear phosphoprotein involved in the transcription of genes central to regulating the cell cycle [2-4], proliferation $[5,6]$, apoptosis [7-9], telomere maintenance $[10,11]$, angiogenesis [12], and differentiation [13]. The c-MYC oncoprotein plays a pivotal role as a regulator of tumorigenesis in numerous human cancers of diverse origin [14-17]. Deregulated expression of c-MYC is often associated with aggressive, poorly differentiated tumors [4]. Deregulation of c-MYC expression is evident in MB with c-MYC gene amplification or aberrant signal transduction of wingless (WNT) signaling pathway [18]. In MB, high c-MYC mRNA expression and c-MYC gene amplification have been described as indicators of poor prognosis [19-22]. Furthermore, two studies have demonstrated that high cMYC mRNA expression is associated with tumor anaplasia $[23,24]$.

Developing therapeutic approaches to inhibit c-MYC would have an enormous impact on the treatment of a wide range of human cancers [25-27]. Many strategies are currently under development to target c-MYC in tumor cells, including inhibitors that block c-MYC expression, such as antisense oligonucleotides and small interfering RNA (siRNA) [28]. One aspect to be considered by evaluating the potential of c-MYC as a novel therapeutic target in $M B$, is its impact on cellular sensitivity to radio- and chemotherapy. In the present study, siRNA-mediated cMYC inhibition was used to study the biological role of cMYC in a representative panel of human MB cells expressing different levels of c-MYC.

\section{Methods}

Human MB cell lines

DAOY (wild-type), DAOY V11 (empty vector-transfected), and DAOY M2 (c-MYC-transfected) human MB cells have been described previously [24]. D341 and D425 human MB cells were the kind gift of Dr Henry Friedman, Duke University, Durham, NC, USA. DAOY, D341, and D425 MB cell lines are derived from three different $M B$ obtained at craniotomy of patients aged 3-5 years $[21,29,30]$. All MB cells were cultured in Richter's zinc option medium (Invitrogen; Basel, Switzerland) supplemented with $10 \%$ fetal bovine serum. Non-essential amino acids were added to the medium of D341 and
D425 cells to a final concentration of $1 \%$, and G418 was added to the medium of DAOY V11 and DAOY M2 to a final concentration of $500 \mu \mathrm{g} / \mathrm{ml}$. All cell cultures were maintained at $37^{\circ} \mathrm{C}$ in a humidified atmosphere with $5 \%$ $\mathrm{CO}_{2}$.

\section{Down-regulation of c-MYC}

The Silencer c-MYC validated siRNA targeting the 3'untranslated region of the human c-MYC mRNA sequence [31,32], referred to here as c-MYC siRNA, and Silencer scrambled c-MYC negative control siRNA, referred to here as control siRNA, having no significant homology to any known gene sequences from mouse, rat, or human, were purchased from Ambion, and used according to the manufacturer's instructions [33]. In brief, small interfering RNAs (siRNAs) for c-MYC and scrambled control siRNA were transfected at a final concentration of 30-60 nM with siPORT amine (Ambion) in the case of DAOY MB cells and with siPORT NeoFX (Ambion) in the case of D341 and D425 MB cells as described before [34,35]. Comparable with other reports we found reproducible inhibition of RNA and protein expression at $48-72 \mathrm{~h}$ post transfection [34,35].

\section{Real-time quantitative polymerase chain reaction}

Total RNA isolation, reverse transcription reactions, and RT-PCR were performed as described previously [36]. Kinetic real-time PCR quantification of target genes was performed using the ABI Prism 7700 Sequence Detection System (Applied Biosystems; Rotkreuz, Switzerland), as described previously [36]. Primers and probes for c-MYC (assay ID: Hs00153408_m1) and the endogenous control 18S rRNA (assay ID: Hs99999901_s1) were purchased from Applied Biosystems (Rotkreuz, Switzerland). Primers and probes for hTERT were purchased from Microsynth (Balgach, Switzerland): forward primer, 5'TGACACCTCACCTCACCCAC-3', reverse primer, 5'CACTGTCTTCCGCAAGTTCAC-3', probe, 5'-ACCCTGGTCCGAGGTGTGTCCCTGAG-3'. Experiments were performed in triplicate for each data point. Relative mRNA expression of target genes was calculated by using the comparative $\mathrm{C}_{\mathrm{T}}$ method [37].

\section{Western blot analysis}

The expression of c-MYC, cyclin-dependent kinase (CDK) inhibitor p21 (waf1/Cip1), caspase-9 and $\beta$-actin protein was assessed by Western blot analysis. In brief, human $\mathrm{MB}$ cells transfected with siRNAs for $72 \mathrm{~h}$ or treated with chemotherapy for $72 \mathrm{~h}$ after $48 \mathrm{~h}$ of transfection with siRNAs, were lysed with lysis buffer $\left(1 \mathrm{ml} / 10^{7}\right.$ cells, $50 \mathrm{mM}$ Tris-HCl buffer [pH 8.0], $150 \mathrm{mM} \mathrm{NaCl}, 1 \%$ Nonidet P40, $0.1 \%$ sodium deoxycholate, $0.1 \%$ sodium dodecylsulfate, $1 \mathrm{mM}$ EDTA, and $1 \mathrm{mM}$ EGTA) containing protease inhibitors (Complete, Roche; Basel, Switzerland) and incubated on ice for $30 \mathrm{~min}$. After measuring the protein 
concentration by the BCA method (Pierce; Rockford, USA), $12 \mu \mathrm{g}$ total protein lysates were separated by $10 \%$ SDS-polyacrylamide gels and the gels were subjected to immunoblotting. Nonspecific binding sites were blocked by $3 \mathrm{~h}$ incubation in TBST ( $10 \mathrm{mM}$ Tris [pH 8.0], $150 \mathrm{mM}$ $\mathrm{NaCl}, 0.05 \%$ Tween-20) supplemented with $5 \%$ non-fat dry milk. Membranes were incubated overnight at $4{ }^{\circ} \mathrm{C}$ with a 1:2000 dilution of rabbit polyclonal anti-c-MYC antibody (Santa Cruz Biotechnology; Heidelberg, Germany), with a 1:1000 dilution of mouse monoclonal antip21 (waf1/Cip1) antibody (Upstate), and with a 1:1000 dilution of rabbit polyclonal antibody specific for cleaved caspase-9 (Cell signaling).

Membranes were then washed three times at room temperature in TBST for 30 min each time, and bound Ig was detected using anti-isotype monoclonal secondary antibody coupled to horseradish peroxidase (Santa Cruz Biotechnology; Heidelberg, Germany). The signal was visualized by enhanced chemiluminescence ECL (Amersham Biosciences; Dübendorf, Switzerland) and autoradiography. Next, immunoblotting with a 1:5000 dilution of a mouse monoclonal primary $\beta$-actin antibody (Sigma; Basel, Switzerland) was performed to verify the protein loading. For densitometry, the zymographic profiles of the gels were scanned. Relative band intensities were determined using Quantity One analysis software (BioRad).

\section{c-MYC transcription factor binding activation assay}

The binding activation of c-MYC was measured using the Mercury TransFactor assay (BD Clontech, Basel, Switzerland), an enzyme-linked immunosorbent assay (ELISA)based assay, according to the manufacturer's instructions, as previously described [36].

\section{Cell proliferation}

Following transfection with siRNAs, a colorimetric $3-(4,5-$ dimethylthiazol-2-yl)-5-(3-carboxymethoxyphenyl)-2(4-sulfophenyl)-2H-tetrazolium inner salt (MTS) assay (Promega; Wallisellen, Switzerland) was used to quantitate cell viability of human $\mathrm{MB}$ cells, as previously described [36]. Each experiment was performed in triplicate. The absorbance values of each well were measured with a microplate spectrophotometer (Molecular Devices; Sunnyvale, CA) at $490 \mathrm{~nm}$. All proliferation assays were repeated as independent experiments at least twice.

\section{Clonogenic survival assay}

A clonogenic survival assay was performed using cells transfected with siRNAs for $48 \mathrm{~h}$, as described previously [38]. The number of single cells seeded was adjusted to obtain around 100 colonies per cell culture dish [39]. Cells were maintained at $37^{\circ} \mathrm{C}$ in a humidified atmosphere containing $5 \% \mathrm{CO}_{2}$ and allowed to grow for 9
(DAOY wt, V11, M2), 14 (D341), or 12 (D425) days respectively, before fixation in methanol/acetic acid (75\%:25\%) and staining with Giemsa. Only colonies with more than 50 cells were counted. All clonogenic assays were repeated as independent experiments at least twice.

\section{Cell cycle analysis}

Cells transfected with siRNAs were harvested after 48 h by trypsinization, washed with PBS $1 \times$, and fixed with $1 \mathrm{ml}$ of $70 \%$ ethanol [38]. After washing twice in PBS, the cells were stained with a solution containing $50 \mu \mathrm{g} / \mathrm{ml}$ propidium iodide (Becton-Dickinson; Allschwil, Switzerland) and $100 \mathrm{U} / \mathrm{ml}$ RNase A (Qiagen; Hombrechtikon, Switzerland) in PBS for $30 \mathrm{~min}$ at room temperature. The percentage of cells in the different phases of the cell cycle was determined by evaluating DNA content according to methods previously described [36]. A total of 30'000 events per sample were acquired. Flow cytometric analysis was performed on a FACSCalibur flow cytometer (BD Biosciences; Allschwil, Switzerland) with CELLQuest software (BD Biosciences). The percentages of cell cycle distribution were calculated on linear PI histograms using the mathematical software ModFit LT 2.0 (Verity Software House; Topsham, ME)

\section{Telomerase activity}

Telomerase activity in $\mathrm{MB}$ cell lines was measured using the Telomerase PCR ELISA kit (Roche Diagnostics; Rotkreuz, Switzerland) as previously described [40]. For this procedure, $10^{6}$ cells were lysed and homogenized in $200 \mu$ l CHAPS buffer. After $30 \mathrm{~min}$ incubation on ice, the lysates were centrifuged at $16,000 \mathrm{~g}$ for $30 \mathrm{~min}$ at $4^{\circ} \mathrm{C}$. Protein concentration was measured using the BCA method (Pierce; Rockford, USA). For the elongation step, $2 \mu \mathrm{l}$ of cell extract ( $2 \mu \mathrm{g}$ protein/ $\mu \mathrm{l}$ ) were incubated in 50 $\mu \mathrm{l}$ reaction mixture at $25^{\circ} \mathrm{C}$ for $30 \mathrm{~min}$ to allow the telomerase to add telomeric repeats (TTAGGG) to the end of the biotin-labeled synthetic P1-TS primer. The products extended by telomerase were then amplified by PCR in the presence of the biotin-labeled P1-TS primer and another primer, P2. Amplification products from the PCR were next immobilized in the well of a StreptAvidin-coated microplate and hybridized to a digoxigenin (DIG)labeled probe specific for the telomeric repeat sequence. Finally, the DIG-labeled hybrids were visualized with a peroxidase-conjugated anti-DIG antibody and a colorimetric peroxidase substrate and quantified photometrically. In order to visualize the typical 6-nucleotide-ladder resulting from the TRAP assay, the amplification products from the PCR were separated by $12.5 \%$ polyacrylamide gel electrophoresis (PAGE), blotted onto a positively charged membrane, and incubated with a StreptAvidin alkaline phosphatase conjugate. The blotted products were visualized by enhanced chemiluminescence (Biotin 
Luminescence Detection Kit Roche Applied Science; Rotkreuz, Switzerland) and autoradiography.

\section{Apoptosis assay}

Cell lysates were obtained from exponentially growing $\mathrm{MB}$ cells transfected with siRNAs for $72 \mathrm{~h}$ and from MB cells treated with etoposide and cisplatin for $72 \mathrm{~h}$ after 48 $\mathrm{h}$ of transfection with siRNAs. A photometric enzyme immunoassay (Cell Death Detection ELISA; Roche Diagnostics, Basel, Switzerland) was used for the quantitative determination of cytoplasmic histone-associated DNA fragments, as described previously [36]. In brief, after the different treatment schedules, cells were counted, and cell lysates of equal number of cells $\left(5 \times 10^{4}\right.$ cells $\left./ \mathrm{ml}\right)$ were placed in a StreptAvidin-coated microtiter plate. A mixture of biotin-labeled monoclonal histone antibody and peroxidase-conjugated monoclonal DNA antibody was then added, followed by incubation for $2 \mathrm{~h}$. After washing to remove unbound antibodies, the amount of mono- and oligonucleosomes was measured at $405 \mathrm{~nm}$ (reference wavelength $490 \mathrm{~nm}$ ).

\section{Chemo- and radio-sensitivity assays}

After $48 \mathrm{~h}$ of transfection with c-MYC siRNA or control siRNA, appropriate numbers of exponentially growing $\mathrm{MB}$ cells were seeded in 96-well plates. Cells were treated for $72 \mathrm{~h}$ with various concentrations of etoposide and cisplatin or were irradiated with 4 Gy and $10 \mathrm{~Gy}$, using a Pantak Therapax $300 \mathrm{kV}$ X-ray unit at $0.7 \mathrm{~Gy} / \mathrm{min}$. Dosimetry was controlled with a Vigilant dosimeter. Cell viability of human MB cells was quantified using the MTS assay $72 \mathrm{~h}$ after adding the chemotherapeutic substances and irradiation, respectively.

\section{Statistical analysis}

All data are expressed as mean $\pm \mathrm{SD}$. Student's t-test was used to test statistical significance. $P<0.05$ was considered to be significant. GraphPad Prism 4 (GraphPad Software, San Diego, California) software was used to calculate $\mathrm{IC}_{50}$ values and their $95 \%$ confidence intervals and to statistically compare the fitted midpoints $\left(\log \mathrm{IC}_{50}\right)$ of the two curves.

\section{Results \\ Targeting c-MYC by siRNA in MB cells}

To establish an efficient method of specifically down-regulating c-MYC expression in MB, we used a siRNA approach. Transfection of human MB cells with siRNA directed against c-MYC resulted in a pronounced downregulation of c-MYC mRNA expression to $21 \%$ in DAOY wt ( $p<0.001), 22 \%$ in DAOY V11 ( $<<0.001), 6 \%$ in DAOY M2 (p < 0.001), 33\% in D341 ( $<<0.001)$, and $65 \%$ in $\mathrm{D} 425(\mathrm{p}=0.017)$ compared with negative control siRNA-transfected cells, as determined by quantitative RTPCR at $48 \mathrm{~h}$ following transfection (Figure 1A). At the pro- tein level, transfection of human MB cells with c-MYC siRNA resulted in a significant down-regulation of c-MYC protein expression compared with negative control siRNA-transfected cells as determined by Western blotting $72 \mathrm{~h}$ post transfection in all $\mathrm{MB}$ cell lines tested (Figure 1B). Transfection of human MB cells with c-MYC siRNA resulted in a significant reduction of c-MYC binding activation to $10 \%$ in DAOY wt ( $\mathrm{p}=0.015), 28 \%$ in DAOY V11 ( $\mathrm{p}=0.009), 21 \%$ in DAOY M2 ( $\mathrm{p}=0.008), 74 \%$ in $\mathrm{D} 341(\mathrm{p}=0.05)$, and 63\% in D425 ( $\mathrm{p}=0.03)$, compared with $\mathrm{MB}$ cells transfected with negative control siRNA at $72 \mathrm{~h}$ following transfection (Figure 1C).

siRNA-mediated c-MYC down-regulation reduces cellular proliferation, inhibits clonogenic growth, induces $\mathrm{GI}$ cell cycle arrest and CDK inhibitor $p 2 I_{\text {(waf } / / C \text { ipl) }}$ expression in MB cells

To test whether siRNA-mediated reduction of c-MYC alters cellular proliferation of human $\mathrm{MB}$ cells, we assessed cell viability at $0,2,4$, and 6 days following cMYC siRNA or control siRNA transfection. When compared with control siRNA-transfected cells, growth was lower in c-MYC siRNA-transfected MB cell lines (Figure 2A). This effect was independent of basal c-MYC expression. We then determined clonogenic survival using $\mathrm{MB}$ cells transfected with control or c-MYC siRNA. After $48 \mathrm{~h}$ of exposure to either c-MYC siRNA or to control siRNA, the siRNA was removed, and clonogenic survival was determined. When compared with control siRNA-transfected cells, the clonogenic survival of c-MYC siRNA-transfected cells was significantly reduced, as observed by decreased number of large colonies (colonies with more than 50 cells), to $67 \%$ in DAOY wt ( $\mathrm{p}=0.011), 78 \%$ in DAOY V11 ( $=0.026), 26 \%$ in DAOY M2 ( $=0.038)$, $52 \%$ in D341 ( $\mathrm{p}=0.003)$, and $59 \%$ in $\mathrm{D} 425(\mathrm{p}=0.001)$ human $\mathrm{MB}$ cells (Figure $2 \mathrm{~B}$ ). We then examined whether alterations in the cell cycle underlie the c-MYC siRNAmediated effect on proliferation of MB cells. Flow cytometric analysis of cells transfected with c-MYC siRNA for $48 \mathrm{~h}$ showed consistent changes in the cell cycle distribution compared with control siRNA-transfected cells. In all cell lines tested, there was an increase in the number of cells in the G0/G1 phase, which was significant in DAOY wt $(\mathrm{p}=0.028)$, DAOY V11 $(\mathrm{p}=0.001)$, DAOY M2 ( $\mathrm{p}=$ $0.033)$, and $\mathrm{D} 341(\mathrm{p}=0.006)$, but slightly below the significance level in D425 ( $\mathrm{p}=0.062)$ (Figure $2 \mathrm{C})$. In all MB cells under study there was a decrease in the number of cells in the S-phase, which was significant in DAOY V11 $(\mathrm{p}=0.005)$ and DAOY M2 ( $\mathrm{p}=0.05)$, compared with control siRNA-transfected cells. The observation that $\mathrm{c}-$ MYC siRNA transfection resulted in an up-regulation of CDK inhibitor p21 (waf1/Cip1) expression compared with control siRNA-transfected cells to $153 \%$ in DAOY wt, $128 \%$ in DAOY V11, 239\% in DAOY M2, $142 \%$ in D 341 , and $198 \%$ in D425, as determined by Western blotting 

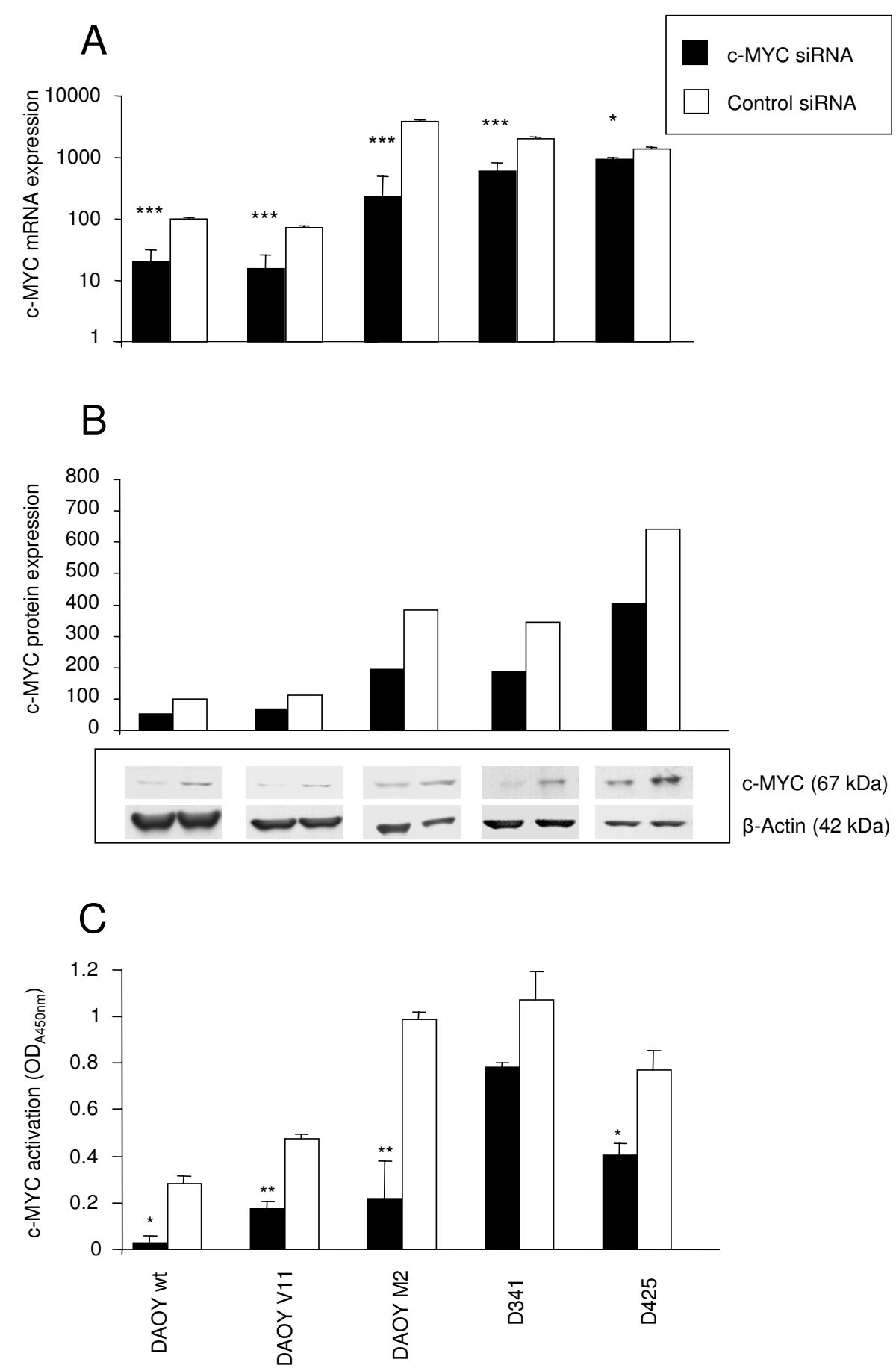

Figure I

Knockdown of c-MYC. c-MYC siRNA reduces c-MYC mRNA (A), protein (B) expression, and binding activity (C) as determined by quantitative RT-PCR, Western blot analysis, and by the ELISA-based TransAM-c-MYC binding activity assay (representative of two to three independent experiments). Values represent levels of c-MYC mRNA ( $n=3$; \pm SD) (A) or protein (B) of control and c-MYC siRNA-transfected cells relative to control siRNA-transfected DAOY wt cells, which was set at 100 (A, B). Data show the mean absorbance $(n=3 ; \pm$ SD) (C). * Significantly different from control values, as determined by the Student's t-test (***: $\mathrm{P}<0.001$, **: $\mathrm{P}<0.01, *: \mathrm{P}<0.05)$. 
A
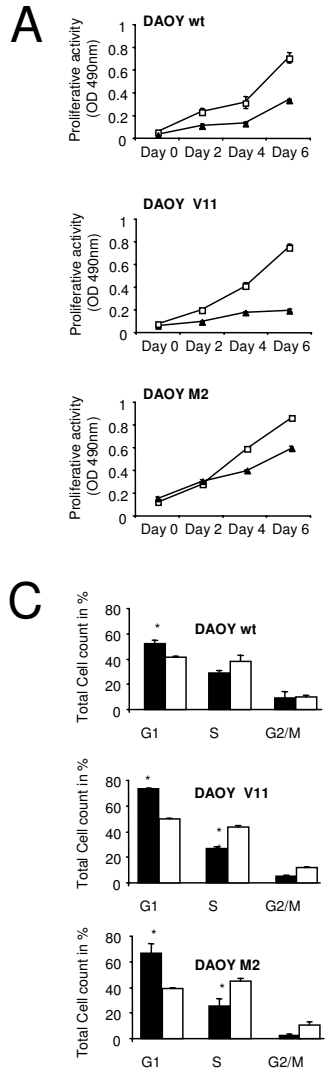

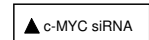

$\square$ Control siRNA

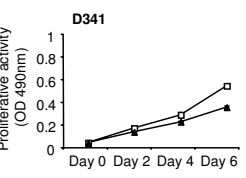

D425
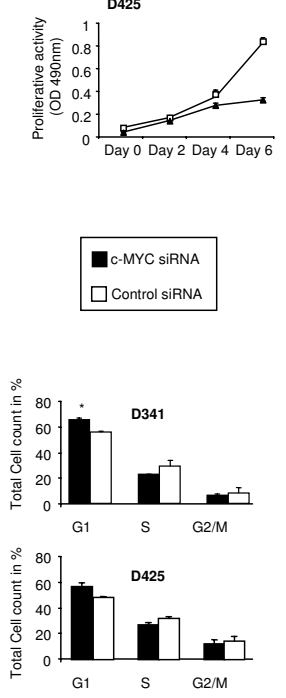

$\mathrm{B}$

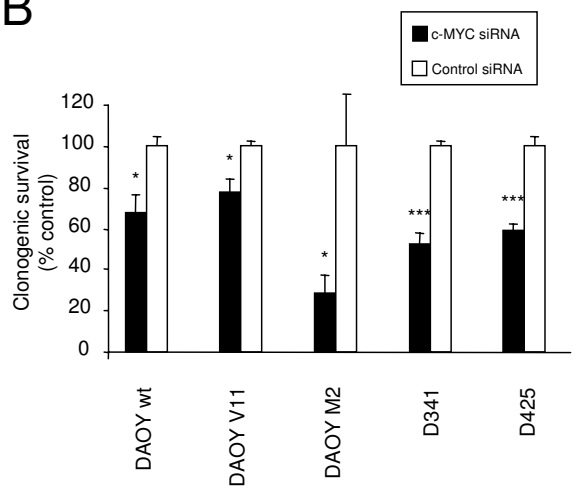

$\mathrm{D}$

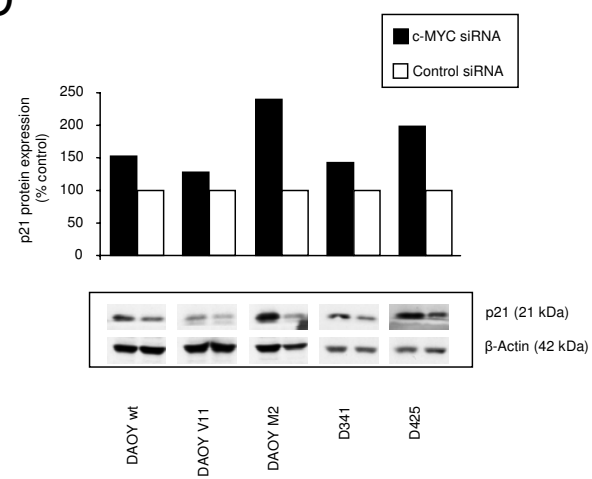

\section{Figure 2}

Knockdown of c-MYC reduces MB cell growth, induces GI cell cycle arrest and CDK inhibitor p2 I (wafl/

Cipl)expression. c-MYC siRNA-transfected cells show reduced cell viability over time and inhibition of clonogenic survival compared with the control siRNA-transfected cells as determined by the MTS assay (A) and by a clonogenic survival assay (B). Cell cycle analysis of control and c-MYC siRNA-transfected cells harvested after $48 \mathrm{~h}$ by trypsinization, fixed in ethanol and stained with propidium iodide as described in Methods. A total number of 30'000 events per sample were counted. Results are presented as the mean percentages of cells in GI, S, and G2/M of two independent experiments ( \pm standard deviation) (C). cMYC siRNA-mediated up-regulation of CDK inhibitor $\mathrm{p} 2 \mathrm{I}$ (wafl/Cipl) expression compared with control siRNA-transfected cells as determined by Western blotting and photometrical quantification at $72 \mathrm{~h}$ post transfection. Values represent the percentage of p2I (wafl/Cipl)relative to control siRNA-transfected cells (D). * Indicates a significant difference compared to control values, as determined by the Student's t-test (***: $\mathrm{P}<0.00 \mathrm{I}$, **: $\mathrm{P}<0.0 \mathrm{I}$, $*$ : $\mathrm{P}<0.05)$.

and photometrical quantification (Figure 2D), was in accordance with the G1 arrest induced by c-MYC downregulation. Taken together, these results demonstrate that down-regulation of c-MYC inhibits tumor cell growth at least partly by induction of cell cycle arrest

\section{siRNA-mediated c-MYC down-regulation reduces apoptotic cell death in MB cells}

To investigate whether the decrease in cellular growth induced by c-MYC down-regulation was also caused by increased levels of apoptosis, we determined apoptotic cell death in siRNA-transfected MB cells (72 h). This anal- ysis revealed that down-regulation of c-MYC resulted in a reduction of apoptosis in all human $\mathrm{MB}$ cell lines tested (Figure 3; DAOY wt: 79\% ( $=0.12)$; DAOY V11: 76\% (p $=0.10)$; DAOY M2: 48\% (p = 0.001); D341: 49\% (p = $0.002), \mathrm{D} 425: 54 \%(\mathrm{p}=0.001))$. This inhibitory effect on apoptosis was more pronounced in human MB cell lines expressing high levels of c-MYC. Cell cycle analysis of control and c-MYC siRNA-transfected cells revealed a decrease in the proportion of cells in sub-G1 when exposed to cMYC siRNA to $74 \%$ in DAOY, to $50 \%$ in DAOY V11, to $47 \%$ in DAOY M2, to $48 \%$ in D341, and to $53 \%$ in D425 $\mathrm{MB}$ cells. 


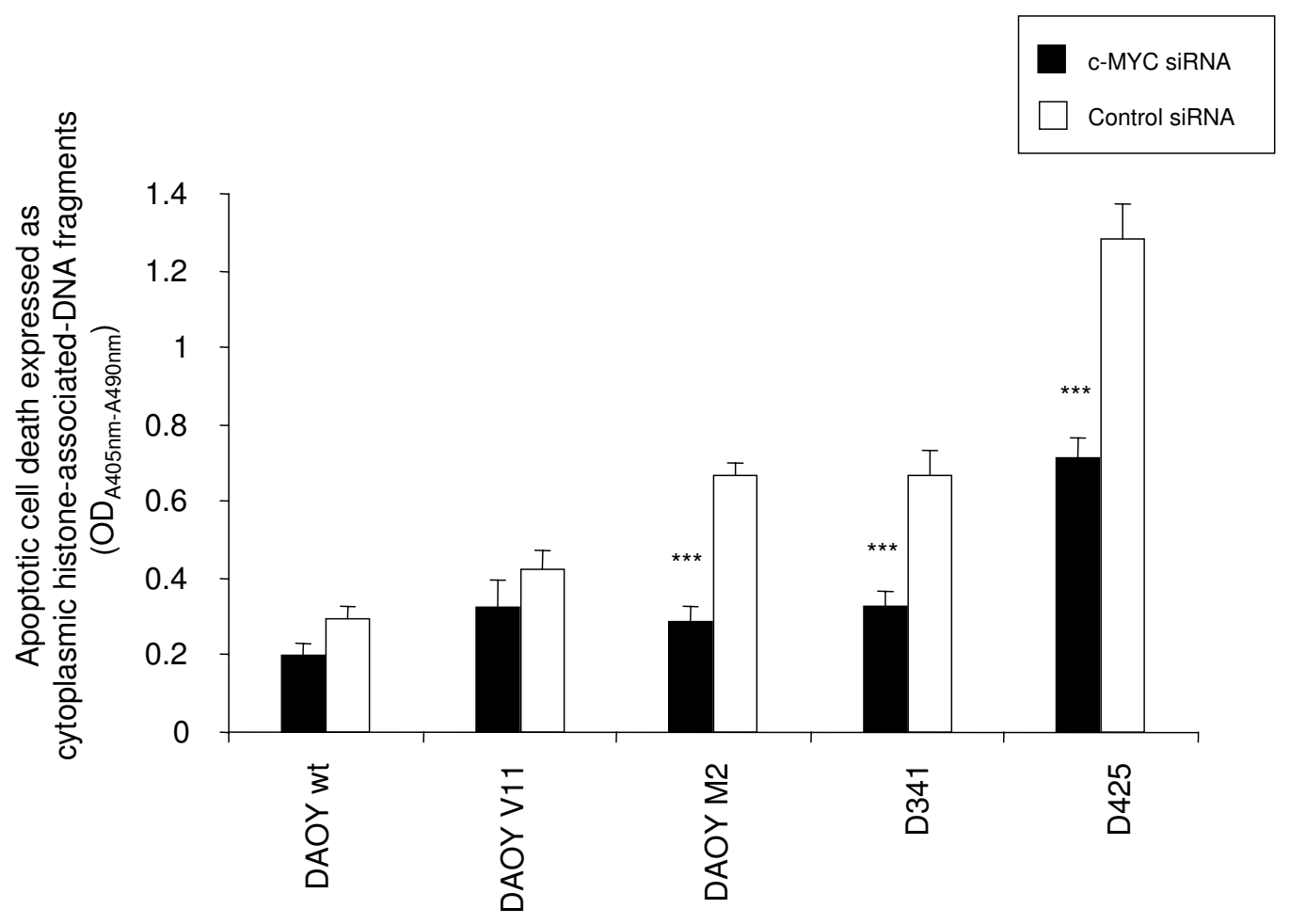

\section{Figure 3}

c-MYC siRNA-mediates a reduction in apoptotic cell death. Reduced apoptotic levels in cells transfected with c-MYC siRNA compared with control siRNA-transfected cells at $72 \mathrm{~h}$ post transfection. Values represent the mean absorbance of cytoplasmatic histone-associated DNA fragments (representative of two independent experiments, $(n=3 ; \pm S D)$ ). * Indicates a significant difference compared to control values, as determined by Student's t-test $(* * *: \mathrm{P}<0.00 \mathrm{I}, * *$ : $\mathrm{P}<0.0 \mathrm{I}$, *: $\mathrm{P}<0.05)$.

siRNA-mediated c-MYC down-regulation reduces $h T E R T$ mRNA expression and telomerase activity in MB cells

To investigate the effects of c-MYC down-regulation on telomerase in $\mathrm{MB}$ cells, we determined hTERT mRNA expression by using quantitative RT-PCR at $48 \mathrm{~h}$ following transfection with c-MYC siRNA or control siRNA. We found a significant reduction of hTERT mRNA expression in c-MYC siRNA-transfected cells to $34 \%$ in DAOY wt, $54 \%$ in DAOY V1 $1,21 \%$ in DAOY M2, $15 \%$ in D341, and $35 \%$ in D425 compared with negative control siRNAtransfected cells, as determined by real-time RT-PCR (Figure 4A). We then determined the effect of c-MYC downregulation on the enzymatic activity of telomerase and performed a modified TRAP assay on cell lysates $72 \mathrm{~h}$ post transfection. This analysis revealed that telomerase activity was inhibited in c-MYC siRNA-transfected DAOY wt, DAOY V11, DAOY M2, and D341 MB cells (Figure 4B).
Telomerase activity was found to be reduced to $77 \%$ in DAOY wt, $79 \%$ in DAOY V11, 63\% in DAOY M2, and $30 \%$ in D341, compared with negative control siRNAtransfected cells (Figure 4C). In D425 MB cells, which are characterized by low TRAP activity [40], c-MYC inhibition did not alter the telomerase activity (Figure 4B,C).

siRNA-mediated c-MYC down-regulation decreases radiosensitivity of MB cells

DAOY, D341, and D425 human MB cells transfected with c-MYC or control siRNA were irradiated with 0,4 , and 10 Gy and cell viability was quantified after 72 h. D341 and D425 were more sensitive to IR than DAOY cells harboring mutant p53 [41] (Figure 5). DAOY M2 cells engineered to express higher c-MYC levels were more susceptible to IR than DAOY wt or DAOY V11 (Figure 5). Compared with control siRNA-transfected cells, c-MYC 

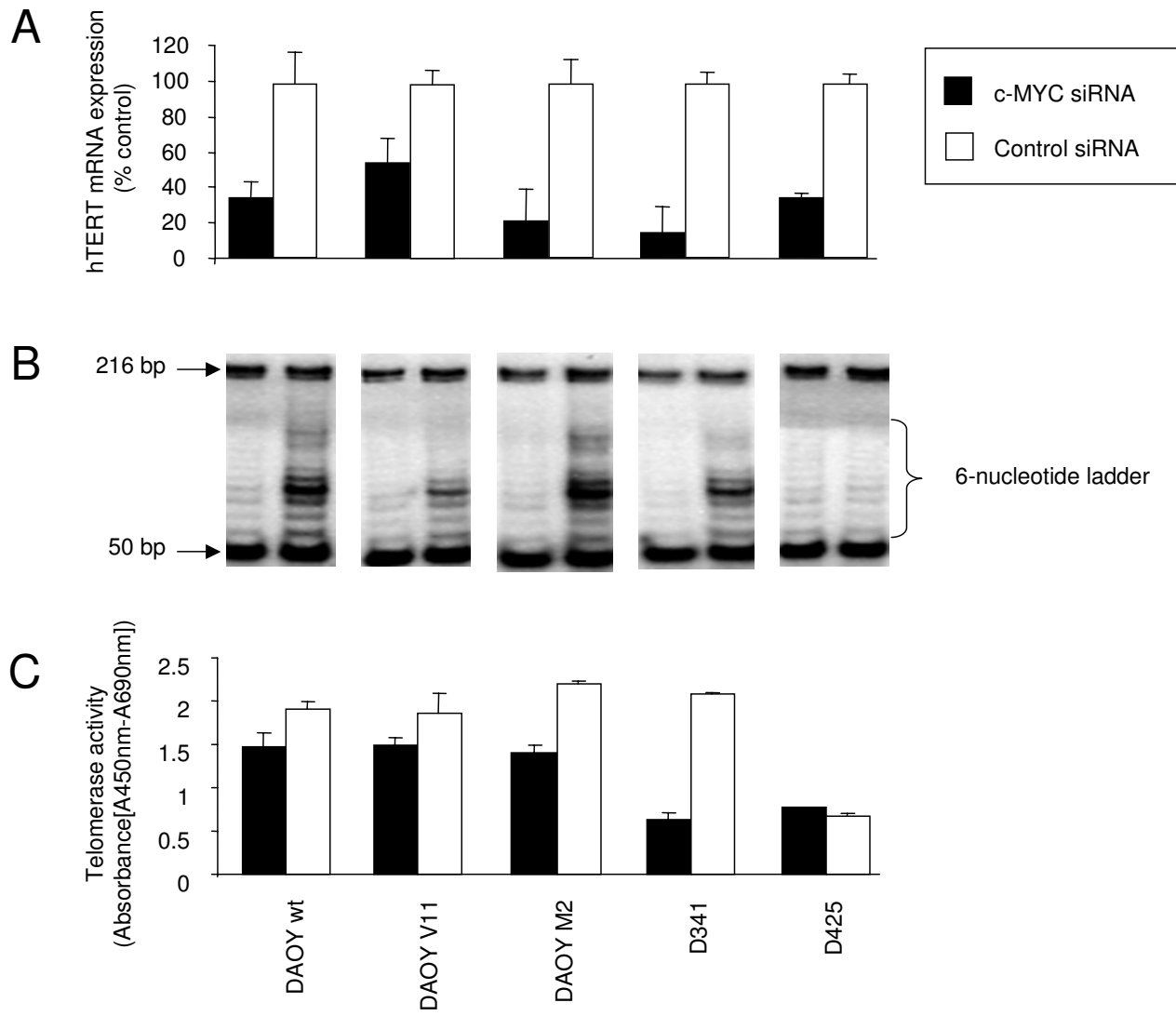

\section{Figure 4}

c-MYC siRNA-mediates inhibition of hTERT mRNA expression and telomerase activity. Inhibition of $h T E R T$ mRNA expression (A) and telomerase activity $(\mathbf{B}, \mathbf{C})$ by c-MYC down-regulation as determined by quantitative RT-PCR (A), by the TRAP assay showing typical products of telomerase activity (6-nucleotide telomerase product ladder) with bands starting from $50 \mathrm{bp}$ and the internal control (IC) in a single band of $216 \mathrm{bp}$ (B), and by the TeloTAGGG telomerase polymerase chain reaction (PCR) enzyme-linked immunosorbent assay (ELISA) kit (C). Values represent the percentage of hTERT mRNA $(n=3 ; \pm S D)$ and mean absorbance $(n=3 ; \pm S D)$ of control and c-MYC siRNA-transfected cells $(\mathbf{A}, \mathbf{C})$.

siRNA-transfected cells were more resistant to killing by IR (Figure 5).

\section{siRNA-mediated c-MYC down-regulation decreases chemo-sensitivity of $M B$ cells}

To investigate whether siRNA-mediated down-regulation of c-MYC alters chemo-sensitivity of MB cells, we measured the cytotoxic response to etoposide and cisplatin. In the case of cisplatin treatment, c-MYC siRNA transfection resulted in a significant decrease in chemo-sensitivity in DAOY M2 ( $<<0.001)$, D425 ( $\mathrm{p}=0.003)$, and D341 ( $\mathrm{p}=$ 0.013 ) (Figure 6A). However, no changes in chemo-sensitivity were observed in DAOY wt and DAOY V11 human $\mathrm{MB}$ cells (Figure 6A). In the case of etoposide treatment, cMYC siRNA transfection resulted in a significant decrease in chemo-sensitivity in DAOY wt $(\mathrm{p}<0.0001)$, DAOY V11 $(\mathrm{p}<0.0001)$, DAOY M2 ( $\mathrm{p}<0.0001)$, and D341 ( $<<$ $0.001)$, and a minor decrease in $\mathrm{D} 425(\mathrm{p}=0.12)$ (Figure 6B).

siRNA-mediated c-MYC down-regulation attenuates the cellular apoptotic response of DAOY MB cells to chemotherapy that is associated with reduced caspase-9 activity

To investigate whether the reduction of chemo-sensitivity induced by c-MYC down-regulation, as measured by cell viability (Figure 6), was caused by decreased levels of apoptosis, we measured the apoptotic cell death in siRNAtransfected (48 h) DAOY M2 cells - showing significant difference in viability following c-MYC down-regulation and treatment with cisplatin and etoposide - after treatment with either cisplatin or etoposide for $72 \mathrm{~h}$. DAOY 

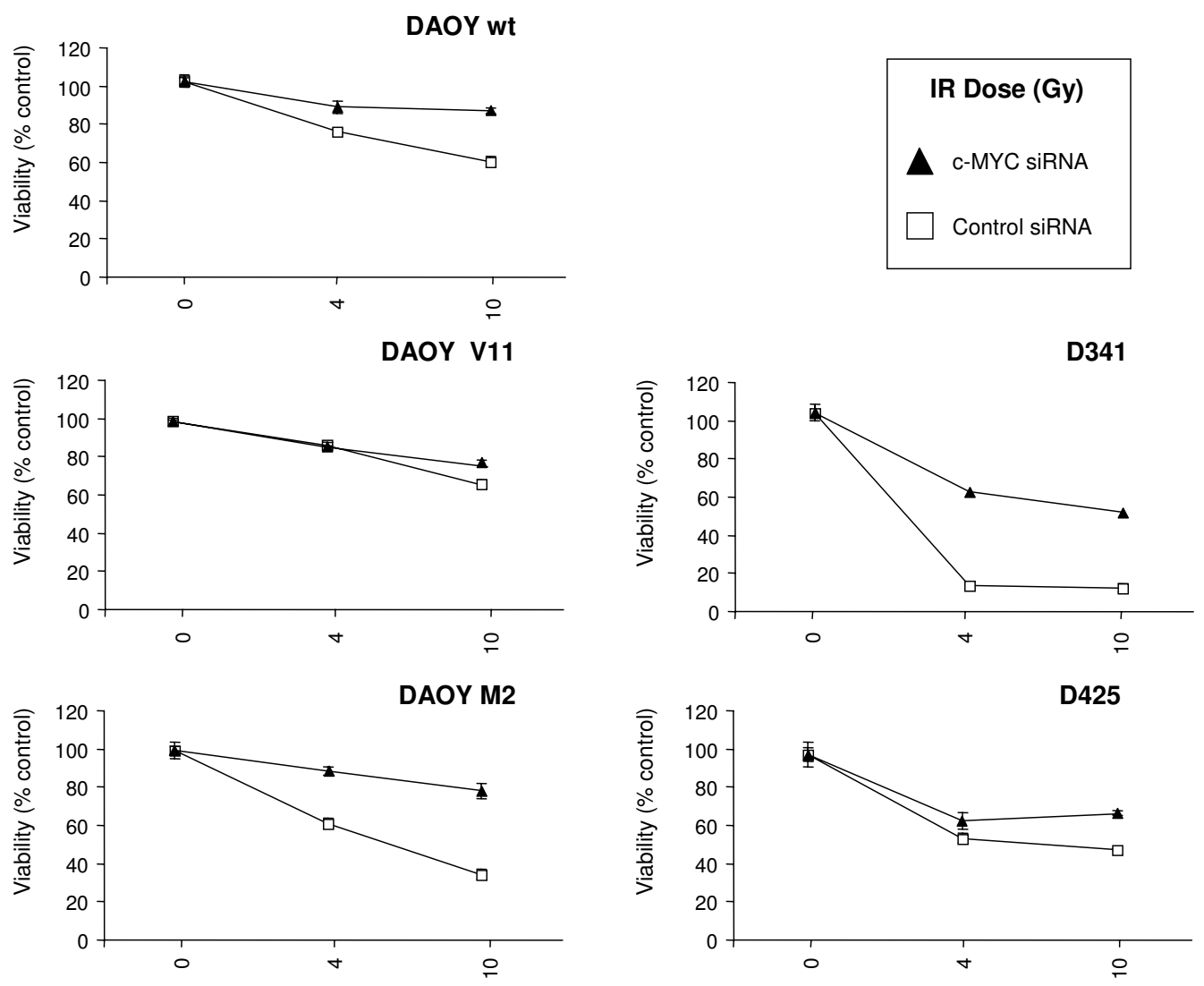

\section{Figure 5}

C-MYC siRNA-mediates reduced susceptibility to ionizing radiation. Cytotoxicity induced by irradiation in c-MYC siRNA and control siRNA-transfected cells was determined by the MTS assay. Values represent the mean percentage of survival \pm SD $(n=3)$ compared to non-irradiated c-MYC siRNA or control siRNA-transfected cells, respectively. $(n=3 ; \pm S D)$.

V11 was included as a control. Following c-MYC downregulation, siRNA-transfected DAOY V11 cells were equally sensitive to cisplatin in terms of viability and induction of apoptosis (Figure 6A, 7A). In the case of etoposide treatment, c-MYC siRNA-treated DAOY V11 cells showed reduced cellular sensitivity (Figure 6B) and only a moderate induction of apoptosis compared to control siRNA-transfected cells (Figure 7B). Treatment of control siRNA-transfected DAOY M2 cells with cisplatin and etoposide resulted in a dose-dependent increase of apoptotic cell death when compared with c-MYC siRNA-transfected DAOY M2 cells. Most of the chemotherapeutics, including cisplatin and etoposide $[42,43]$, induce apoptosis mainly through the mitochondrial pathway. Mitochondria-mediated apoptosis involves the cleavage of pro-caspase- 9 into the active caspase-9. Next, we examined processing of caspase- 9 in DAOY M2 cells, trans- fected with siRNAs for $48 \mathrm{~h}$ and treated for $72 \mathrm{~h}$ with cisplatin and etoposide. More caspase- 9 cleavage was detected in control siRNA-transfected cells compared to cMYC siRNA-transfected DAOY M2 cells as determined by Western blotting. This analysis suggests that down-regulation of c-MYC inhibits the apoptotic response to chemotherapy that appears at least partly mediated by caspase- 9 .

\section{Discussion}

Whereas the impact of c-MYC gene amplification and cMYC mRNA over-expression on MB histology and prognosis has been investigated intensively [19-24], the biological functions of c-MYC in $\mathrm{MB}$ cells remain largely elusive. To our knowledge, the current study represents the first comprehensive analysis of c-MYC targeting in a representative panel of human $\mathrm{MB}$ cells expressing different levels of c-MYC. 

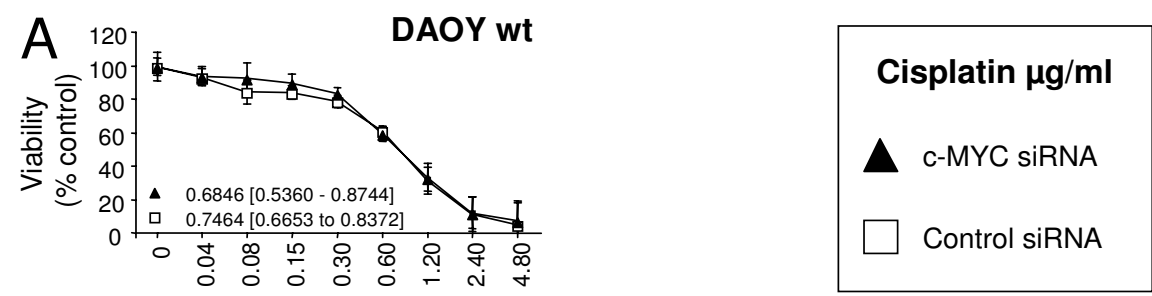

DAOY V11
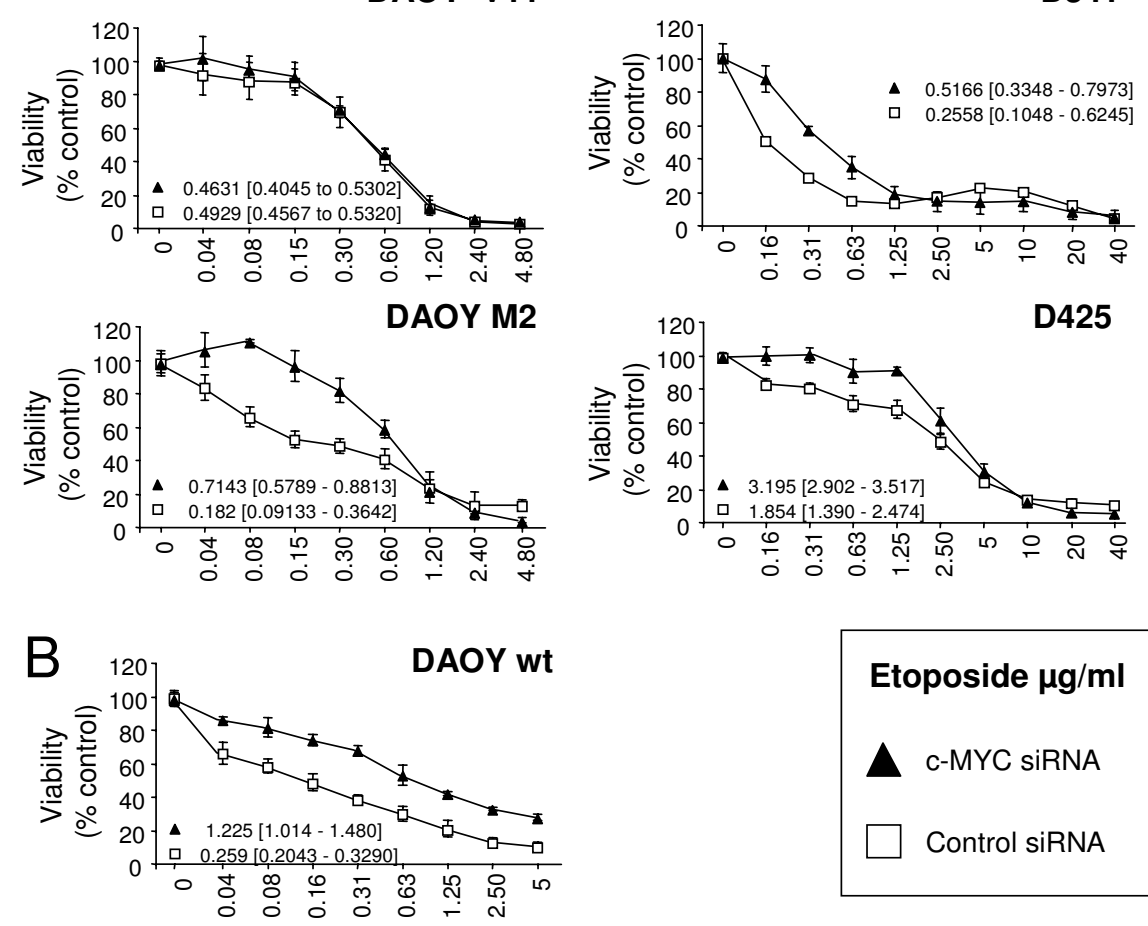

\section{Etoposide $\mu \mathrm{g} / \mathrm{ml}$}

$\triangle$ c-MYC siRNA

Control siRNA
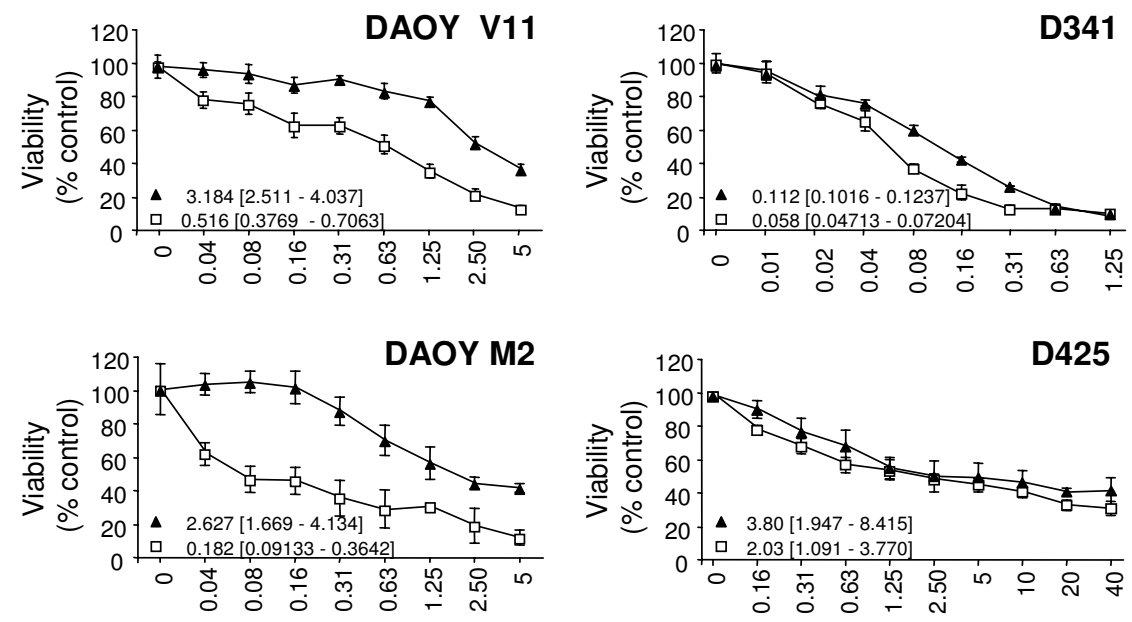

\section{Figure 6}

C-MYC siRNA-mediates reduced susceptibility to cisplatin (A) and etoposide (B) treatment. Cytotoxicity induced by etoposide and cisplatin in c-MYC siRNA and in control siRNA-transfected cells was determined by the MTS assay. Values represent the mean percentage of survival compared to control cells $(n=3 ; \pm S D)$. The $I_{50}$ values and their $95 \%$ confidence intervals were calculated from the regression curve and are indicated for each data set. 


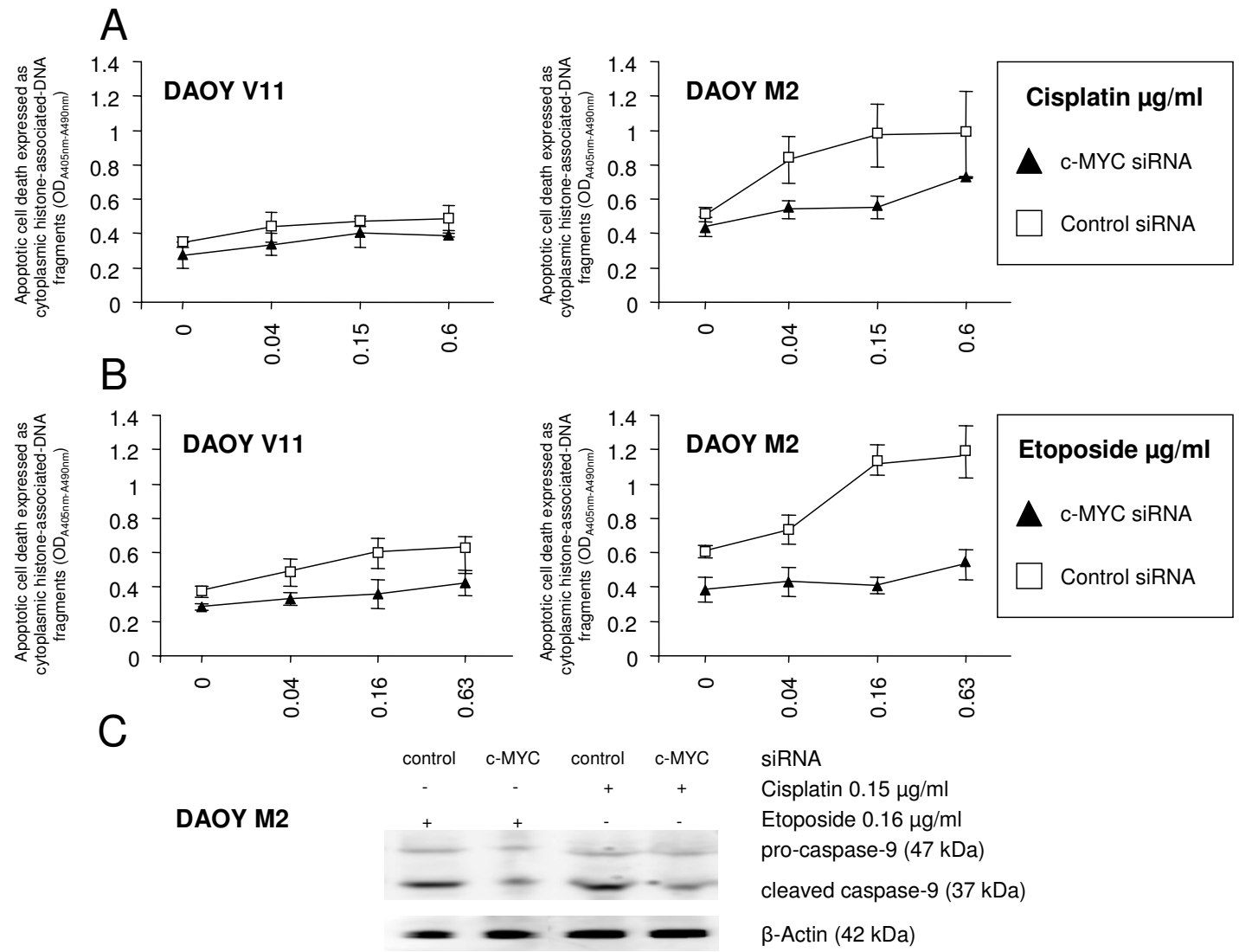

\section{Figure 7}

C-MYC siRNA-mediates inhibition of cisplatin- and etoposide-induced apoptosis (A, B) in DAOY MB cells that is associated with reduced processing of caspase-9(C). Minor $(\mathbf{A})$ and moderate $(B)$ induction of apoptosis in DAOY VII cells transfected with siRNAs and exposed to cisplatin and etoposide, respectively. Markedly reduced apoptosis in DAOY M2 cells transfected with c-MYC siRNA compared to control siRNA-transfected cells upon cisplatin and etoposide treatment (A, B). Reduced processing of caspase-9 in c-MYC siRNA-transfected DAOY M2 cells after cisplatin and etoposide treatment as assessed by Western blot analysis (C). Actin was used as a loading control. Values represent the mean absorbance of cytoplasmatic histone-associated DNA fragments (representative of two independent experiments, $(n=3 ; \pm S D)$ ).

siRNA-mediated c-MYC down-regulation resulted in an anti-proliferative effect in all human MB cell lines tested. Moreover, the ability of c-MYC siRNA-treated MB cells to form large colonies was significantly reduced. Down-regulation of c-MYC expression resulted in an activation of the CDK inhibitor p21 and in a cell cycle arrest at the G0/ G1 phase. These results are supported by findings from others, demonstrating that c-MYC represses the p21 promoter [44], and showing that c-MYC over-expression in primary human fibroblasts results in inhibition of p21 transcription [45]. Moreover, the G1-S progression of eukaryotic cells is in part controlled by c-MYC $[2,4,7]$. Ectopic expression of c-MYC in quiescent cells promotes the entry into the S-phase $[46,47]$. On the other hand, down-regulation of c-MYC expression by antisense meth- ods resulted in anti-proliferative effects by preventing Sphase entry $[48,49]$. Our investigation shows that c-MYC inhibition reduces tumor cell growth suggesting that cMYC might be an attractive target in MB to inhibit tumor growth.

siRNA-mediated c-MYC down-regulation resulted in a down-regulation of hTERT mRNA expression and in a reduction of telomerase activity in all but D425 human MB cells. D425 cells are characterized by relatively low hTERT mRNA expression and TRAP-negativity [40]. However, the absence of significant correlation between c-MYC and hTERT expression and the difference seen between hTERT mRNA and activity inhibition could be attributed to the presence of several binding sites for other transcrip- 
tion factors - than c-MYC - on hTERT gene promoter and to the fact that expression of hTERT mRNA is not the only regulator of telomerase activity [50-52]. Alternative splicing [53], posttranscriptional modification [54,55], subcellular hTERT localization [56] and the presence of enzyme inhibitors may alter telomerase activity. Moreover, it has been suggested that a threshold level of hTERT protein is required in order for telomerase to become active, therefore low levels of hTERT mRNA may not indicate active telomerase [57]. In this respect, hTERT expression has not been found to correlate with telomerase activity in colorectal tumors [58]. Furthermore, hTERT mRNA expression has been detected in lymphocytes regardless of telomerase activity [59] and in some normal telomerase negative tissues such as human brain, prostate liver and ovary [60]. Telomerase impairment can lead to the induction of apoptosis through a mechanism that relies on the inhibition of telomerase catalytic activity and on the consequent telomere shortening $[61,62]$. However, depending on the telomere length, this mechanism is rather slow. Several generations and a long lag time may be required before telomeres shorten below a critical length [62-64]. Holt et al. have showed that cells with elongated telomeres are more resistant to induction of apoptosis than their parental counterparts with short telomeres [65]. Our experiments were executed in a short time window $(72 \mathrm{~h})$ due to cell distress upon treatment with c-MYC siRNA.

DAOY M2 cells engineered to stably over-express c-MYC show higher basal apoptotic activity compared with DAOY wt and DAOY V11 cells, and are characterized by enhanced apoptosis rate in vivo [24]. D425 and D341 MB cells (both with c-MYC gene amplification and high cMYC expression) also show a higher basal apoptotic rate when compared with DAOY wt cells. Moreover, c-MYC inhibition resulted in a significant decrease in the apoptotic rate which was most pronounced in $\mathrm{MB}$ cells with high c-MYC expression. It has been shown that c-MYC can drive cells to undergo apoptosis [7-9]. However, this might not be the case for all cell lines. In UW-228 human $\mathrm{MB}$ cells, down-regulation of c-MYC by an antisense approach resulted not only in an inhibition of cell growth but also in an increase of apoptosis as determined by FACS analysis [66].

We then analyzed whether c-MYC down-regulation alters sensitivity to IR and chemotherapeutic agents and found a decrease in the sensitivity to IR, cisplatin, and etoposide. This effect was most prominent in cells expressing high cMYC levels. The differences of cytotoxic effect of cisplatin and etoposide on siRNA-transfected MB cells may be due to the different mode of action that the two drugs exert. The cytotoxicity of cisplatin is mediated by its interaction with DNA to form DNA adducts, which activate several signal transduction pathways and terminate in the activation of apoptosis [67], whereas etoposide belongs to the class of topoisomerase II poison with the ability to stabilize complex between DNA topoisomerase II and DNA that results in a high level of DNA damage [43]. By addressing the question of whether c-MYC alters the response of cells to radio- and chemotherapy, results have been conflicting [68-74]. Our results are in agreement with studies demonstrating that c-MYC sensitize a variety of cells to different cytotoxic treatments [68-70], and that absence of c-MYC expression might confer resistance to anti-cancer agents [71]. However, this effect of c-MYC also seems to be cell type-specific. In human melanoma cells, a decrease in c-MYC expression has been reported to enhance the effect of IR [72] and cisplatin treatment $[73,74]$.

Cancer chemotherapies induce apoptosis [42]. Changes that decrease the ability to activate the apoptotic machinery might affect the sensitivity of cells to a range of chemotherapeutic agents. In order to evaluate whether c-MYC down-regulation affects the susceptibility to apoptosis, we investigated the apoptotic response of siRNAs-transfected DAOY M2 cells following cisplatin and etoposide treatment. This cell line was used, because c-MYC inhibition caused significant reduction of chemo-sensitivity to cisplatin and etoposide. This analysis revealed that down-regulation of c-MYC attenuated drugs-induced apoptosis that was associated with a reduced caspase-9 processing. These results are consistent with findings from other groups showing that C-MYC inhibition mediates resistance to chemotherapy-induced apoptosis by preventing activation of caspase-mediated pathways $[68,69,71]$.

\section{Conclusion}

Taken together, our data show for the first time that targeting c-MYC in human MB cells decreases cell growth, induces cell cycle arrest and reduces telomerase activity. However, c-MYC down-regulation also causes decreased apoptosis and resistance towards IR, cisplatin, and etoposide. Following in vivo validation, targeting c-MYC might represent a promising strategy to reduce tumor growth in pretreated $\mathrm{MB}$ patients whose tumors have ceased to respond to chemotherapy. Our data also indicate that targeting c-MYC might not be used concomitantly with chemotherapy or radiotherapy in MB because of the risk of reducing the effectiveness of these therapies.

Emerging evidence indicates that the different precursor cell populations that form the cerebellum and the cell signaling pathways that regulate its development likely represent distinct compartments from which the variable subtypes of $M B$ arise $[75,76]$. It remains to be tested whether down-regulation of c-MYC has MB subtype specific effects or is rather $\mathrm{MB}$ subtype independent. 


\section{Competing interests}

The authors declare that they have no competing interests.

\section{Authors' contributions}

AOVB performed most experimental work including data analysis and he drafted the manuscript. TS participated in the study design and supervised the experimental work. AOVB and COJ carried out together the irradiation experiments under the supervision of MP. DS and CGE stably transfected the DAOY cell lines and participated in study design and data analysis. LA contributed in some experiments. MAG guided the study and finalized the manuscript. AA helped by finalizing the manuscript. All authors read and approved the final manuscript.

\section{Acknowledgements}

This study was financially supported by the Swiss National Fonds and the Swiss Research Foundation Child and Cancer.

\section{References}

I. Gurney JG, Smith MA, Bunin GR: CNS and miscellaneous intracranial and intraspinal neoplasms. SEER Pediatric Monograph 2000:51-63 [http://seer.cancer.gov/publications/]. National Cancer Institute

2. Obaya AJ, Mateyak MK, Sedivy JM: Mysterious liaisons: the relationship between c-Myc and the cell cycle. Oncogene 1999, I 8(19):2934-294I.

3. Schorl C, Sedivy JM: Loss of protooncogene c-Myc function impedes GI phase progression both before and after the restriction point. Mol Biol Cell 2003, I 4(3):823-835.

4. Pelengaris S, Khan M, Evan G: c-MYC: more than just a matter of life and death. Nat Rev Cancer 2002, 2(10):764-776.

5. Schmidt EV: The role of c-myc in cellular growth control. Oncogene 1999, 18:2988-2996.

6. Trumpp A, Refaeli Y, Oskarsson T, Gasser S, Murphy M, Martin GR, Bishop JM: c-Myc regulates mammalian body size by controlling cell number but not cell size. Nature 2001, 4|4(6865):768-773.

7. Prendergast GC: Mechanisms of apoptosis by c-Myc. Oncogene 1999, I 8(19):2967-2987.

8. Evan GI, Wyllie AH, Gilbert CS, Littlewood TD, Land H, Brooks M, Waters CM, Penn LZ, Hancock DC: Induction of apoptosis in fibroblasts by c-myc protein. Cell 1992, 69(I): | | 9-128.

9. Nilsson JA, Cleveland JL: Myc pathways provoking cell suicide and cancer. Oncogene 2003, 22(56):9007-902I.

10. Wang J, Xie LY, Allan S, Beach D, Hannon G]: Myc activates telomerase. Genes Dev 1998, I 2(1 2): I769-1774.

II. Wu KJ, Grandori C, Amacker M, Simon-Vermot N, Polack A, Lingner J, Dalla-Favera R: Direct activation of TERT transcription by cMYC. Nat Genet 1999, 2 I(2):220-224.

12. Baudino TA, McKay C, Pendeville-Samain H, Nilsson JA, Maclean KH, White EL, Davis AC, Ihle JN, Cleveland JL: c-Myc is essential for vasculogenesis and angiogenesis during development and tumor progression. Genes Dev 2002, I 6( I 9):2530-2543.

13. Henriksson M, Luscher B: Proteins of the Myc network: essential regulators of cell growth and differentiation. Adv Cancer Res 1996, 68: 109-182

14. Felsher DW, Bishop JM: Reversible tumorigenesis by MYC in hematopoietic lineages. Mol Cell I999, 4(2): 199-207.

15. Shachaf CM, Kopelman AM, Arvanitis C, Karlsson A, Beer S, Mandl S, Bachmann MH, Borowsky AD, Ruebner B, Cardiff RD, Yang Q, Bishop JM, Contag $\mathrm{CH}$, Felsher DW: MYC inactivation uncovers pluripotent differentiation and tumour dormancy in hepatocellular cancer. Nature 2004, 43 I (70 I 2): I I I2- I I 7.

16. D'Cruz CM, Gunther EJ, Boxer RB, Hartman JL, Sintasath L, Moody SE, Cox JD, Ha SI, Belka GK, Golant A, Cardiff RD, Chodosh LA: cMYC induces mammary tumorigenesis by means of a preferred pathway involving spontaneous Kras2 mutations. Nat Med 200I, 7(2):235-239.
17. Arnold I, Watt FM: c-Myc activation in transgenic mouse epidermis results in mobilization of stem cells and differentiation of their progeny. Curr Biol 200 I, I I (8):558-568.

18. Gilbertson RJ: Medulloblastoma: signalling a change in treatment. Lancet Oncol 2004, 5(4):209-2 I8.

19. Rutkowski S, von Bueren A, von Hoff K, Hartmann W, Shalaby T, Deinlein F, Warmuth-Metz M, Soerensen N, Emser A, Bode U, Mittler U, Urban C, Benesch M, Kortmann RD, Schlegel PG, Kuehl J, Pietsch T, Grotzer M: Prognostic Relevance of Clinical and Biological Risk Factors in Childhood Medulloblastoma: Results of Patients Treated in the Prospective Multicenter Trial HIT'9 I. Clin Cancer Res 2007, I 3(9):265I-2657.

20. Grotzer MA, Hogarty MD, Janss AJ, Liu X, Zhao H, Eggert A, Sutton LN, Rorke LB, Brodeur GM, Phillips PC: MYC messenger RNA expression predicts survival outcome in childhood primitive neuroectodermal tumor/medulloblastoma. Clin Cancer Res 200I, 7(8):2425-2433.

2I. Bigner SH, Friedman HS, Vogelstein B, Oakes WJ, Bigner DD: Amplification of the c-myc gene in human medulloblastoma cell lines and xenografts. Cancer Res 1990, 50:2347-2350.

22. Herms J, Neidt I, Lüscher B, Sommer A, Schürmann P, Schröder T, Bergmann M, Wilken B, Probst-Cousin S, Hernaiz-Driever P, Behnke J, Hanefeld F, Pietsch T, Kretzschmar HA: C-myc expression in medulloblastoma and its prognsotic value. Int J Cancer 2000, 89:395-402

23. Eberhart CG, Kratz J, Wang Y, Summers K, Stearns D, Cohen K, Dang CV, Burger PC: Histopathological and molecular prognostic markers in medulloblastoma: c-myc, N-myc, TrkC, and anaplasia. I Neuropathol Exp Neurol 2004, 63(5):44I-449.

24. Stearns D, Chaudhry A, Abel TW, Burger PC, Dang CV, Eberhart CG: c-myc overexpression causes anaplasia in medulloblastoma. Cancer Res 2006, 66(2):673-68I.

25. Nesbit CE, Tersak JM, Prochownik EV: MYC oncogenes and human neoplastic disease. Oncogene 1999, I 8(19):3004-3016.

26. Ponzielli R, Katz S, Barsyte-Lovejoy D, Penn LZ: Cancer therapeutics: targeting the dark side of Myc. Eur J Cancer 2005, 4I(I6):2485-250I.

27. Vita M, Henriksson M: The Myc oncoprotein as a therapeutic target for human cancer. Semin Cancer Biol 2006, I6(4):3 I 8-330.

28. Hermeking $\mathrm{H}$ : The MYC oncogene as a cancer drug target. Curr Cancer Drug Targets 2003, 3(3):163-175.

29. Jacobsen PF, Jenkyn DJ, Papadimitriou JM: Establishment of a human medulloblastoma cell line and its heterotransplantation into nude mice. J Neuropathol Exp Neurol 1985, 44:472-485.

30. Friedman HS, Burger PC, Bigner SH, Trojanowski JO, Brodeur GM, He XM, Wikstrand CJ, Kurtzberg J, Berens ME, Halperin EC, Bigner DD: Phenotypic and genotypic analysis of a human medulloblastoma cell line and transplantable xenograft (D34I Med) demonstrating amplification of c-myc. Am J Pathol 1988, 130:472-484.

31. Demeterco C, Itkin-Ansari P, Tyrberg B, Ford LP, Jarvis RA, Levine F: c-Myc controls proliferation versus differentiation in human pancreatic endocrine cells. I Clin Endocrinol Metab 2002, 87(7):3475-3485.

32. Swarbrick A, Akerfeldt MC, Lee CS, Sergio CM, Caldon CE, Hunter LJ, Sutherland RL, Musgrove EA: Regulation of cyclin expression and cell cycle progression in breast epithelial cells by the helix-loop-helix protein Id I. Oncogene 2005, 24(3):38I-389.

33. Koshiji M, Kageyama Y, Pete EA, Horikawa I, Barrett JC, Huang LE: HIF-I alpha induces cell cycle arrest by functionally counteracting Myc. Embo J 2004, 23(9): 1949-1956.

34. Fan X, Mikolaenko I, Elhassan I, Ni X, Wang Y, Ball D, Brat DJ, Perry A, Eberhart CG: Notch I and notch2 have opposite effects on embryonal brain tumor growth. Cancer Res 2004 64(2I):7787-7793.

35. Di C, Liao S, Adamson DC, Parrett TJ, Broderick DK, Shi Q, Lengauer C, Cummins JM, Velculescu VE, Fults DW, McLendon RE, Bigner DD, Yan $\mathrm{H}$ : Identification of OTX2 as a medulloblastoma oncogene whose product can be targeted by all-trans retinoic acid. Cancer Res 2005, 65(3):919-924.

36. von Bueren AO, Shalaby T, Rajtarova J, Stearns D, Eberhart CG, Helson L, Arcaro A, Grotzer MA: Anti-proliferative activity of the quassinoid NBT-272 in childhood medulloblastoma cells. BMC Cancer 2007, 7(I): 19 .

37. Giulietti A, Overbergh L, Valckx D, Decallonne B, Bouillon R, Mathieu $C$ : An overview of real-time quantitative PCR: applications 
to quantify cytokine gene expression. Methods 200I, 25(4):386-40I.

38. Narayanan BA, Narayanan NK, Davis L, Nargi D: RNA interference-mediated cyclooxygenase-2 inhibition prevents prostate cancer cell growth and induces differentiation: modulation of neuronal protein synaptophysin, cyclin DI, and androgen receptor. Mol Cancer Ther 2006, 5(5): I I I7-I I 25.

39. Zaugg K, Rocha S, Resch H, Hegyi I, Oehler C, Glanzmann C, Fabbro $D$, Bodis S, Pruschy M: Differential p53-dependent mechanism of radiosensitization in vitro and in vivo by the protein kinase C-specific inhibitor PKC4I 2. Cancer Res 200I, 6 I (2):732-738.

40. Didiano D, Shalaby T, Lang D, Grotzer MA: Telomere maintenance in childhood primitive neuroectodermal brain tumors. Neuro-oncol 2004, 6( I): I-8.

4I. Saylors RL III, Sidransky D, Friedman HS, Bigner SH, Bigner DD, Vogelstein B, Brodeur GM: Infrequent p53 gene mutations in medulloblastomas. Cancer Res 1991, 5 I:472 I-4723.

42. Kaufmann SH, Earnshaw WC: Induction of apoptosis by cancer chemotherapy. Exp Cell Res 2000, 256(I):42-49.

43. Montecucco A, Biamonti G: Cellular response to etoposide treatment. Cancer Lett 2007, 252(I):9-18.

44. Gartel AL, Ye X, Goufman E, Shianov P, Hay N, Najmabadi F, Tyner AL: Myc represses the $\mathbf{p}$ I (WAFI/CIPI) promoter and interacts with Sp I/Sp3. Proc Natl Acad Sci USA 200I, 98(8):45I 0-45I5

45. Coller HA, Grandori C, Tamayo P, Colbert T, Lander ES, Eisenman RN, Golub TR: Expression analysis with oligonucleotide microarrays reveals that MYC regulates genes involved in growth, cell cycle, signaling, and adhesion. Proc Natl Acad Sci USA 2000, 97(7):3260-3265.

46. Kaczmarek L, Hyland JK, Watt R, Rosenberg M, Baserga R: Microinjected c-myc as a competence factor. Science 1985 228(4705): $|3| 3-13 \mid 5$.

47. Eilers M, Schirm S, Bishop JM: The MYC protein activates transcription of the alpha-prothymosin gene. Embo J |99|, I0(1):|33-|4|.

48. Heikkila R, Schwab G, Wickstrom E, Loke SL, Pluznik DH, Watt R, Neckers LM: A c-myc antisense oligodeoxynucleotide inhibits entry into $S$ phase but not progress from $\mathbf{G O}_{0}$ to GI. Nature 1987, 328(6 | 29):445-449.

49. Holt JT, Redner RL, Nienhuis AW: An oligomer complementary to c-myc mRNA inhibits proliferation of $\mathrm{HL}-60$ promyelocytic cells and induces differentiation. Mol Cell Biol 1988, 8(2):963-973.

50. Flores I, Benetti R, Blasco MA: Telomerase regulation and stem cell behaviour. Curr Opin Cell Biol 2006, I 8(3):254-260.

5I. Aisner DL, Wright WE, Shay JW: Telomerase regulation: not just flipping the switch. Curr Opin Genet Dev 2002, I 2(I):80-85.

52. Maser RS, DePinho RA: Keeping telomerase in its place. Nat Med 2002, 8(9):934-936.

53. Ulaner GA, Hu JF, Vu TH, Oruganti H, Giudice LC, Hoffman AR: Regulation of telomerase by alternate splicing of human telomerase reverse transcriptase (hTERT) in normal and neoplastic ovary, endometrium and myometrium. Int / Cancer 2000, 85(3):330-335

54. Li H, Zhao L, Yang Z, Funder JW, Liu JP: Telomerase is controlled by protein kinase Calpha in human breast cancer cells. J Biol Chem 1998, 273(50):33436-33442.

55. Kang SS, Kwon T, Kwon DY, Do SI: Akt protein kinase enhances human telomerase activity through phosphorylation of telomerase reverse transcriptase subunit. J Biol Chem 1999, 274( I 9): I 3085- I 3090.

56. Wong JM, Kusdra L, Collins K: Subnuclear shuttling of human telomerase induced by transformation and DNA damage. Nat Cell Biol 2002, 4(9):73I-736.

57. Snijders PJ, van Duin M, Walboomers JM, Steenbergen RD, Risse EK, Helmerhorst TJ, Verheijen RH, Meijer CJ: Telomerase activity exclusively in cervical carcinomas and a subset of cervical intraepithelial neoplasia grade III lesions: strong association with elevated messenger RNA levels of its catalytic subunit and high-risk human papillomavirus DNA. Cancer Res 1998 , 58(17):3812-3818.

58. Tahara H, Yasui W, Tahara E, Fujimoto J, Ito K, Tamai K, Nakayama J, Ishikawa F, Tahara E, Ide T: Immuno-histochemical detection of human telomerase catalytic component, hTERT, in human colorectal tumor and non-tumor tissue sections. Oncogene 1999, I8(8): |56|-I567.
59. Liu K, Schoonmaker MM, Levine BL, June $\mathrm{CH}$, Hodes RJ, Weng NP: Constitutive and regulated expression of telomerase reverse transcriptase (hTERT) in human lymphocytes. Proc Natl Acad Sci USA 1999, 96(9):5।47-5|52.

60. Ramakrishnan S, Eppenberger U, Mueller H, Shinkai Y, Narayanan R: Expression profile of the putative catalytic subunit of the telomerase gene. Cancer Res 1998, 58(4):622-625.

6I. Mondello C, Scovassi Al: Telomeres, telomerase, and apoptosis. Biochem Cell Biol 2004, 82(4):498-507.

62. Deng Y, Chan SS, Chang S: Telomere dysfunction and tumour suppression: the senescence connection. Nat Rev Cancer 2008, 8(6):450-458.

63. Pilch DR, Sedelnikova OA, Redon C, Celeste A, Nussenzweig A, Bonner WM: Characteristics of gamma-H2AX foci at DNA double-strand breaks sites. Biochem Cell Biol 2003, 8I(3): I23-I29.

64. Takai H, Smogorzewska A, de Lange T: DNA damage foci at dysfunctional telomeres. Curr Biol 2003, I3( I 7):1549-I 556.

65. Holt SE, Glinsky VV, Ivanova AB, Glinsky GV: Resistance to apoptosis in human cells conferred by telomerase function and telomere stability. Mol Carcinog 1999, 25(4):24I-248.

66. Zhang P, Li H, Wu ML, Chen XY, Kong QY, Wang XW, Sun Y, Wen S, Liu J: c-Myc downregulation: a critical molecular event in resveratrol-induced cell cycle arrest and apoptosis of human medulloblastoma cells. J Neurooncol 2006, 80(2): | 23-|3|

67. Siddik $\mathrm{ZH}$ : Cisplatin: mode of cytotoxic action and molecular basis of resistance. Oncogene 2003, 22(47):7265-7279.

68. Albihn A, Loven J, Ohlsson J, Osorio LM, Henriksson M: c-Mycdependent etoposide-induced apoptosis involves activation of Bax and caspases, and PKCdelta signaling. J Cell Biochem 2006, 98(6): $1597-16 \mid 4$.

69. Adachi S, Obaya AJ, Han Z, Ramos-Desimone N, Wyche JH, Sedivy JM: c-Myc is necessary for DNA damage-induced apoptosis in the G(2) phase of the cell cycle. Mol Cell Biol 200I, 2I(I 5):4929-4937.

70. Maclean KH, Keller UB, Rodriguez-Galindo C, Nilsson JA, Cleveland JL: c-Myc augments gamma irradiation-induced apoptosis by suppressing Bcl-XL. Mol Cell Biol 2003, 23(20):7256-7270.

7I. Grassilli E, Ballabeni A, Maellaro E, Del Bello B, Helin K: Loss of MYC confers resistance to doxorubicin-induced apoptosis by preventing the activation of multiple serine protease- and caspase-mediated pathways. J Biol Chem 2004, 279(20):2/3|8-2|326.

72. Bucci B, D'Agnano I, Amendola D, Citti A, Raza GH, Miceli R, De Paula U, Marchese R, Albini S, Felsani A, Brunetti E, Vecchione A: Myc down-regulation sensitizes melanoma cells to radiotherapy by inhibiting MLHI and MSH2 mismatch repair proteins. Clin Cancer Res 2005, I I(7):2756-2767.

73. Biroccio A, Benassi B, Amodei S, Gabellini C, Del Bufalo D, Zupi G: c-Myc down-regulation increases susceptibility to cisplatin through reactive oxygen species-mediated apoptosis in MI4 human melanoma cells. Mol Pharmacol 200I, 60(I): I74-I82.

74. Leonetti C, Biroccio A, Candiloro A, Citro G, Fornari C, Mottolese $M$, Del Bufalo D, Zupi G: Increase of cisplatin sensitivity by cmyc antisense oligodeoxynucleotides in a human metastatic melanoma inherently resistant to cisplatin. Clin Cancer Res 1999, 5(9):2588-2595.

75. Gilbertson RJ, Ellison DW: The origins of medulloblastoma subtypes. Annu Rev Pathol 2008, 3:34|-365.

76. Fan X, Eberhart CG: Medulloblastoma stem cells. J Clin Oncol 2008, 26(I7):282I-2827.

\section{Pre-publication history}

The pre-publication history for this paper can be accessed here:

http://www.biomedcentral.com/1471-2407/9/10/prepub 